\title{
Kendra Taira Field, Growing Up with the Country: Family, Race, and Nation after the Civil War (New Haven, CT: Yale University Press, 2018). 256 pp. Cloth \$38.00.
}

Kendra Taira Field has written a compelling social and biographical history of black American immigration and racial uplift movements after the Civil War by contextualizing the experiences of the author's own extended family. Field unearths historic treasures by doing history "in her own backyard" so to speak. Encouraged by a mentor to turn a genealogical hobby into a dissertation, Field employs methodology that complicates the local and global interrelationships of America's freedom generation and serves as an example of why aspiring historians should take seriously "the important place of narratives and storytelling within families and communities" (x).

Field loosely structures the book both thematically and chronologically by pairing movements in black American history such as westward expansion, the allblack town movement, and black nationalism with contemporary family patriarchs: Thomas Jefferson Brown, James Monroe Coleman, and Alexander "Elic" Davis. Throughout the work, she reminds the reader that these acts of racial collectivity are informed by broader movements in American history, including "the rise of racial nationalism, settler expansion, and domestic and overseas imperialism, as well as the continuing influence of what came before-knowledge and experiences of migration, land, freedom, and privilege rooted in the antebellum period" (13).

The narrative begins with Thomas Jefferson Brown. Born free in Arkansas in the 1850 s, he was the first in the family to immigrate to Indian Territory during the first decades of federal oversight of white settler expansion and competing native territorial claims. The author does not flinch in situating Brown's desire to own land within the larger story of American annexation of native lands. While arguing in favour of the "basic humanity of all peoples," she warns about racially mythologizing black resistance during the Nadir, writing hers are "a people irrevocably disaffected by contemporary white nationalism, yet who also participated in American expansionism as "settlers on Indian land" (12-13).

The book then turns to James Monroe Coleman, whose story began with him being born a slave in Mississippi. His odyssey illustrates how after Emancipation black southerners' hope for interracial accord in their strivings toward racial uplift transition to a resignation that racial uplift would occur only through racial separation as demonstrated by the formation of all-black towns. As black political power violently, and at times abruptly, dissipated throughout the South, Field situates Coleman's decision to leave Mississippi within the larger context of racialized terror. In 
the late 1880s, nearby racial attacks such as the Carrollton Massacre and the notorious lynching of black grocers in Memphis "added fuel to the fire," further motivating Coleman to emigrate and establish the all-black settlement of Mantee, Oklahoma, named after his home in Mississippi (84).

Spanning from Mound Bayou, Mississippi to the west coast of Africa, in the last two chapters of the monograph Field theorizes about the shared vectors of black domestic and international migration movements through the life of Alexander "Elic" Davis. Field reexamines the Chief Alfred Sam movement of the early twentieth century, disavowing its "shyster" portrayal in the historiography for an objective consideration of its shortcomings caused by factors such as colonial bureaucracy, land disputes, the influenza epidemic, and world war. She rejects the characterization of post-Civil War black emigration as disjointed efforts to various destinations. Viewing them as one wide-ranging movement bound by the strategy of migration, she contends they reveal that "rural emigration to black settlements across Kansas, Indian Territory, Oklahoma, and West Africa functioned for many freedpeople, as a response to political and economic exclusion, poverty, and violence at the nadir" (106).

Studies of social and class status are also woven into the narrative. For Thomas Jefferson Brown, nationality, not race, was the most prescient factor in his ability to acquire and keep land as a member of the Creek nation in Indian Territory. Monroe Coleman, born of mixed parentage, was able to capitalize on his white heritage and relative higher status in Reconstruction-era Mississippi. Instead of being apprenticed like his cousin Elic, Monroe attended school and, when ready, was able to leave the state with at least some possessions and capital. Elic Davis's progeny knew they had not "gotten up in the world" like their Coleman cousins, but never understood why. Recounting Elic's childhood as an orphan, toil as an exploited sharecropper, and escape from Mississippi under the cover of darkness, Field elucidates the sequence of events leading to the disparate outcomes within the family.

Though Field's work is organized around male members of the family tree, women are prominently featured throughout. Both of Thomas Jefferson Brown's wives, Aurelia and Judith, were of Creek ancestry. As the Creek nation practiced matrilineality, it was only in his marriage to them that his goal of land ownership could be realized. Kaziah Miller, Monroe Coleman's mother, made the calculated decision to initially remain close to her former owner, who in all probability raped her and fathered Monroe, in order to both shelter her son from and prepare him for the heightened perils of life as a black man outside his birthplace. Like her mother before her, as a child Della Davis, Elic's wife, had been forced to leave her family and immigrate west as slaveholders opened up new areas of the South for cultivation. Her difficult plight as a former slave, like that of her husband, drove her willingness to support immigration movements. Seeking protection against sexual assault, black women were simultaneously motivation for and partners in the formation of "potential black space" $(8,104)$. 
Though arguing to the contrary, the structure of the book facilitates a fragmented view of racial uplift and migration. The overlapping nature of territorial separatist movements in the 1870s, 1880s, 1890s, and early twentieth century could be further advanced. Surely in the 1870s Brown also migrated to Indian Territory to escape racial terror in Arkansas, but Field omits this assessment, instead highlighting it as motivation for Coleman and Davis in the 1880s and 1890s. In truth, the motivations of each participant intersect. Similarly, although Field's is primarily a narrative account, a more quantitative analysis of outward migration, particularly in Mississippi, could be used to argue its frequency as a strategy during the period. The sources that Field does choose to include are thoroughly interrogated. Family histories are supplemented with secondary sources for contextualization. She uses a variety of sources to fill in the gaps left by these family histories including newspapers and first-person narratives of similarly situated black southerners, as well as US census and Indian population registers.

Overall, Field's work is an exceptional read. Though beginning as a family history, it is not the work of a lay historian. While describing her family's past, Field instructs the reader on broader themes in African American history. It is simple, yet complex, straightforward, yet thoughtful and a model of how to broaden black genealogical history so that it sits squarely in the American story.

Selena Sanderfer Doss

Western Kentucky University 